4 norden 



\section{Analysis of Enforcement According to REACH}

TemaNord 2006:542 


\section{Analysis of Enforcement According to REACH}

TemaNord 2006:542

(C) Nordic Council of Ministers, Copenhagen 2006

ISBN 92-893-1361-7

Copies: Print-on-Demand

This publication can be ordered on www.norden.org/order. Other Nordic publications are available at www.norden.org/publications

Nordic Council of Ministers

Store Strandstræde 18

DK-1255 Copenhagen K

Phone (+45) 33960200

Fax $(+45) 33960202$

www.norden.org

\section{Nordic Council}

Store Strandstræde 18

DK-1255 Copenhagen K

Phone (+45) 33960400

Fax $(+45) 33111870$

\section{Nordic Environmental Co-operation}

The Nordic Environmental Action Plan 2005-2008 forms the framework for the Nordic countries' environmental co-operation both within the Nordic region and in relation to the adjacent areas, the Arctic, the EU and other international forums. The programme aims for results that will consolidate the position of the Nordic region as the leader in the environmental field. One of the overall goals is to create a healthier living environment for the Nordic people.

\section{Nordic co-operation}

Nordic co-operation, one of the oldest and most wide-ranging regional partnerships in the world, involves Denmark, Finland, Iceland, Norway, Sweden, the Faroe Islands, Greenland and Åland. Cooperation reinforces the sense of Nordic community while respecting national differences and similarities, makes it possible to uphold Nordic interests in the world at large and promotes positive relations between neighbouring peoples.

Co-operation was formalised in 1952 when the Nordic Council was set up as a forum for parliamentarians and governments. The Helsinki Treaty of 1962 has formed the framework for Nordic partnership ever since. The Nordic Council of Ministers was set up in 1971 as the formal forum for co-operation between the governments of the Nordic countries and the political leadership of the autonomous areas, i.e. the Faroe Islands, Greenland and Åland. 


\section{Table of Contents}

Preface

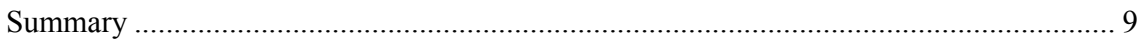

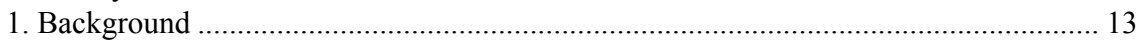

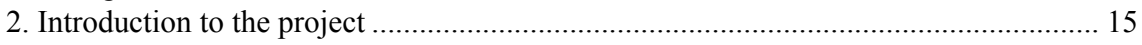

3. The content of the examination and working method.................................................... 17

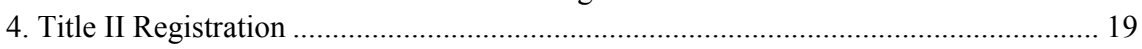

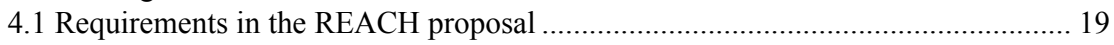

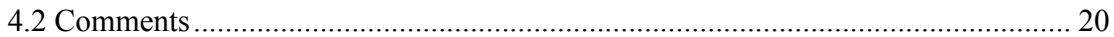

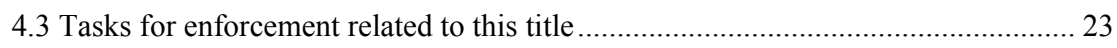

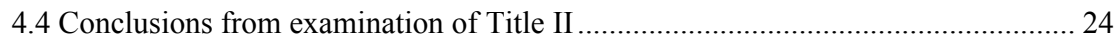

5. Title III Data sharing and avoidance of unnecessary testing...................................... 25

5.1 Requirements in the REACH proposal ............................................................. 25

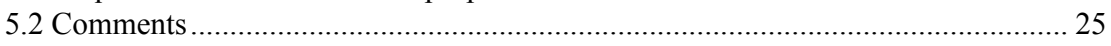

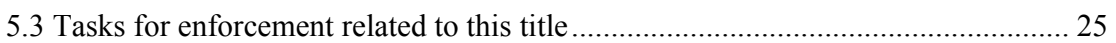

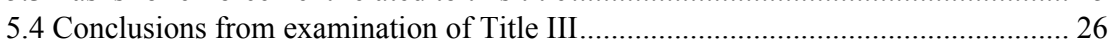

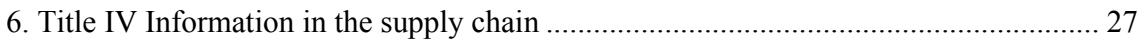

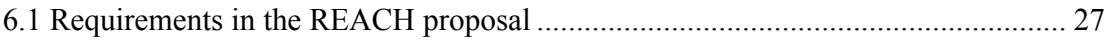

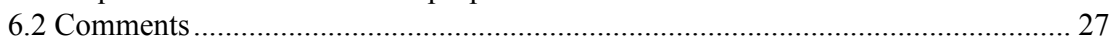

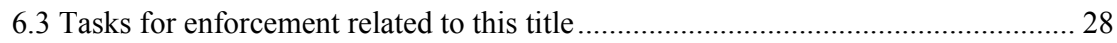

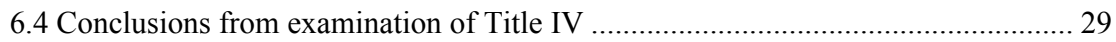

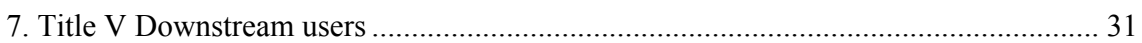

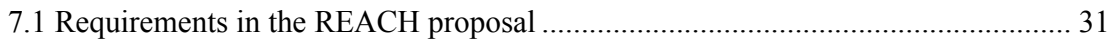

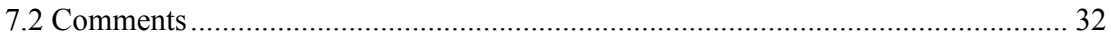

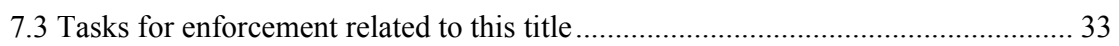

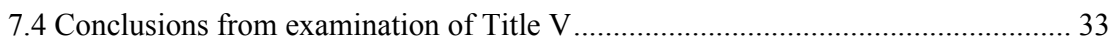

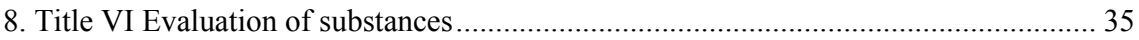

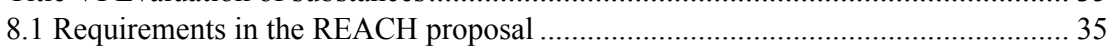

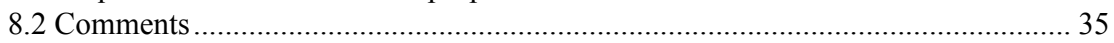

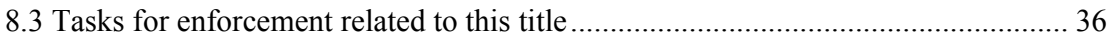

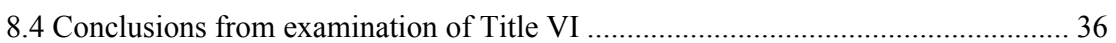

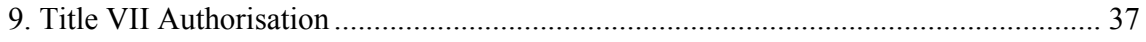

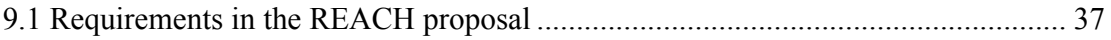

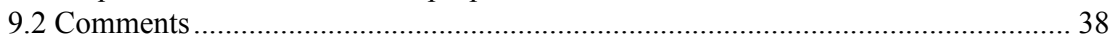

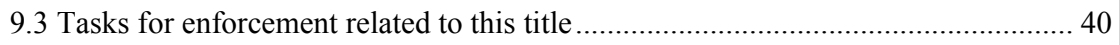

9.4 Conclusions from examination of Title VII ............................................................. 40

10. Title VIII Restrictions on the manufacturing, marketing and use of certain

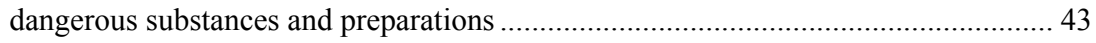

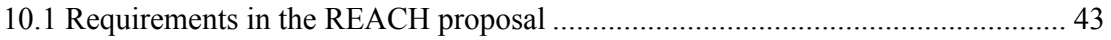

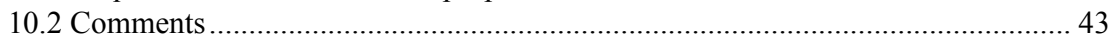

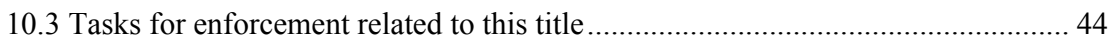

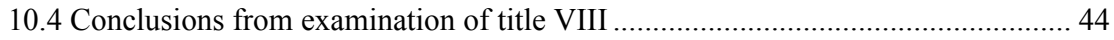

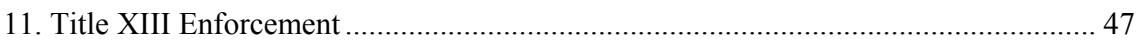

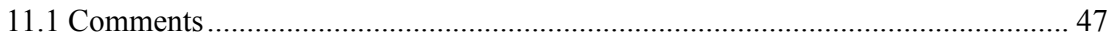

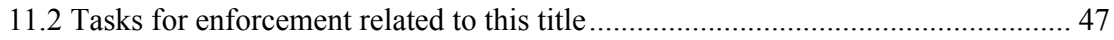

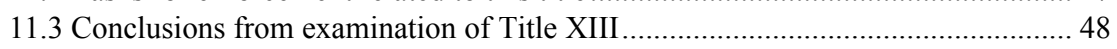

12. Development of a guideline for inspection of manufacturer/ importer ....................... 49

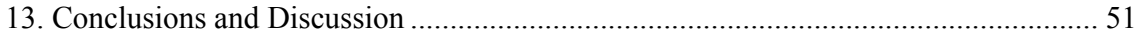

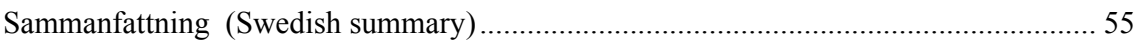

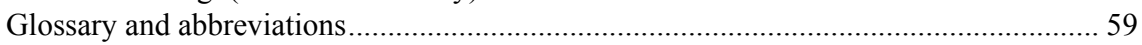

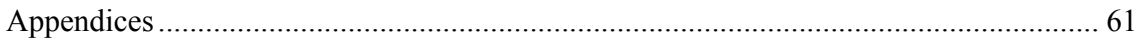





\section{Preface}

This is a report of a joint Nordic project aimed to examine the main titles (registration, evaluation, authorisation and restrictions) of the Commissions REACH proposal of October 2003 from an enforcement perspective.

The project has resulted in, among others, viewpoints on enforceability of REACH, new demands on enforcement authorities, enforcement methods and need for co-operation between enforcement authorities. Based on this project, a proposal for a European enforcement project on REACH, has been prepared by Sweden in cooperation with other Nordic countries.

The project was carried out by a project group with the following members: Barbro Sillrén (project leader), National Chemicals Inspectorate in Sweden, Pia Petersen, Danish Environmental Protection Agency, Annette Ekman, National Product Control Agency for Welfare and Health in Finland and Maren Wikheim, Norwegian Pollution control Authority. 



\section{Summary}

On 29 October 2003, the European Commission launched its proposal for a new chemical legislation concerning the Registration, Evaluation, Authorisation and Restriction of Chemicals (REACH). The Commission has started several REACH implementation projects (RIP) with the aim of developing guidance documents for industry and authorities, but none of these include development of guidance on enforcement.

In August 2004, the Nordic Council of Ministers decided by granting funds, to start a joint Nordic project on "Analysis of the enforcement according to REACH". The objective of the project was to examine, from an enforcement perspective, the main titles (registration, evaluation, authorisation and restrictions) of the Commissions REACH proposal of October 2003. The examination was to result in proposals and viewpoints on enforceability of REACH and how REACH will affect today's enforcement. It was to point out possibilities for and obstacles to enforcement of the proposed Regulation text, new demands on enforcements authorities, enforcement methods and cooperation between enforcement authorities and Member States. The results of the project were also meant to be used at national level to further cooperation between enforcement authorities in the Nordic countries, in the upcoming cooperation in FORUM as well as on-going cooperation in CLEEN. The aim was also to provide input to the Nordic countries in the negotiation process. However, there have been changes in the proposal of 2003, but these changes have not been reflected in this project since they were published after the main examination work was done.

Based on this Nordic project, a proposal for a European enforcement project on REACH has been prepared by Sweden in cooperation with other Nordic countries. The proposal was presented to the Commission Working Group (CWG) on REACH in March 2006, and it was decided to carry out the project. At the same meeting a subgroup under CWG (PreForum) was appointed to organise and start the work in the Forum.

REACH (Article 122) points out, that the Member States have to maintain a system of official controls and other activities as appropriate in the circumstances. They are to lay down the penalty provisions applicable for infringement of the provisions of the Regulation and take all measures necessary to ensure that they are implemented (Article 123). REACH does not contain any conditions or requirements as to enforcement nor are any tasks of the enforcement authorities specified anywhere.

A Forum for Exchange of Information on Enforcement, will be organised under the Agency, and will coordinate harmonised enforcement projects and joint inspections. Another task for the Forum is to develop 
working methods and tools for inspectors. Nothing is mentioned in REACH about any "help desk" for the enforcement authorities, but it is considered important and helpful in matters of guidance on interpretation and decisions if the enforcement methods were to be as harmonised as possible.

REACH means new challenges for enforcement in the Member States. There is a need to educate inspectors and to increase knowledge about the Regulation itself and the new enforcement tasks. Workable procedures for cooperation between different enforcement authorities need to be established at the national level as well as an effective enforcement organisation in order to make REACH function in reality. As each Member State will have only one representative in Forum, this further underlines the need for effective cooperation.

A new task and a big challenge for enforcers will be to decide if substances should be registered or if they are outside the scope of REACH or covered by any of the many exemptions. This requires knowledge of other EU legislation mentioned in REACH as well as general knowledge of chemistry and process technology.

The most hazardous substances will in future be listed in an annex to the Regulation and have to be authorised for a specific use. Authorisation will also be a new important task for enforcers. For example, one challenge will be all the exemptions and how conditions are complied with by the downstream users in the supply chain (when downstream users can use their suppliers' authorisation).

Parts of the REACH proposal consists of existing legislation, e.g. Council Directive 76/769/EEC relating to restrictions on the marketing and use of certain dangerous substances and preparations and the Safety Data Sheet Directive (91/155/EEC). Enforcement of these regulations will continue after REACH has entered into force, e.g. whether substances/preparations are classified correctly, information in the safety data sheet and correlation with information on the label. There is a need to specify the governing rank and precedence of REACH and other special EU-legislation e.g. a clarification of whether the restrictions in REACH also cover articles which can be considered as toys or medical devices.

Enforcers of REACH need access to relevant information in the Agency's database e.g. registration numbers, time-limits, conditions, sunset dates, exemptions or notification from downstream users. REACH does not make it clear enough to what extent enforcement authorities have access to the database and to confidential information.

The Global Harmonised System (GHS) will probably enter into force as a Regulation at the same time as REACH. This means that it is necessary to investigate how these Regulations will work together as GHS regulates how substances/preparations are to be classified and how SDS are to be prepared. 
The Downstream Users perspective has not been analysed in depth in this project. Due to the fact that the Nordic Countries have mostly Downstream Users, it could be of interest to further analyse the situation with regard to enforcement for those companies. As one and the same company may be importer, manufacturer and downstream user, REACH may affect the company, and the enforcement, in many different ways.

Feedback from enforcement authorities to the Competent Authority or to the Agency could be of importance, for example how substances/preparations are used, if conditions are met or if they are impossible to comply with, substances that might be candidates for authorisation or restrictions and if there are any results of monitoring. If this is considered as important, it has to be further investigated.

The first reading of the Commissions REACH proposal has now been concluded at the European Council and the European Parliament. The second reading in Council and Parliament is expected to be concluded during autumn 2006. REACH Regulations will probably come into force during spring 2007. 



\section{Background}

REACH - a new Regulation was proposed by the Commission on 29 October 2003 (COM (2003) 644 Final). This new Regulation will replace about 40 existing Directives and Regulations on chemicals, in one single Regulation. The proposed Regulation contains rules about chemical substances on their own, in preparations and in articles. To adequately control the risks arising from the manufacture, import, placing on the market and use of substances, the REACH proposal reverses the burden of proof from authorities to industry for information on chemical substances and using this information to assess the safety of chemicals and select appropriate risk management measures. To reflect this the proposed Regulation states in Article 1 that it is based on the principle that it is up to manufacturers, importers and downstream users of substances to ensure that they manufacture, place on the market or import or use such substances in a way that does not adversely affect human health or the environment.

REACH creates a single legislation for both "existing" and "new" chemicals. Its basic elements are:

- Registration - general obligation for manufacturers and importers of substances (on their own, in preparations and if intentionally released from articles) to submit a registration for each substance manufactured or imported in quantities of 1 tonne or above per year.

- Evaluation

There are two types of evaluation:

i) a dossier evaluation, where the authorities check compliance with the registration requirements. This is not a formal approval; it only implies that the documents comply with the registration requirements. If there is no compliance, industry has to supply further information

ii) a substance evaluation, where information provided by industry about a substance of concern forms the basis of the authorities evaluation of the substance, which later may lead to proposals under authorisations or restrictions

It has to be noted that the evaluation process do not cover every substance or registration dossier.

- Authorisation - substances with properties of very high concern will be made subject to authorisation for specified use/uses and conditions. 
- Restriction - manufacture, placing on the market or use of certain dangerous substances may either be subject to conditions or prohibition.

- European Chemicals Agency -will manage the technical, scientific and administrative aspects of the REACH system at Community level, aiming to ensure that REACH functions well.

- Information - on hazards and risks and how to manage them should be passed up and down the supply chain. Quality of information should be improved by the Regulation requirements.

A European Chemicals Agency will be established to manage the technical, scientific and administrative aspects of the REACH system, and ensuring consistency of decision making, at Community level. It should consist of a Management Board, an Executive Director and Committees for Member States, Risk Assessment and Socio-economic Analysis, and a FORUM for exchange of information on enforcement. In the REACH proposal, the Commission formulates the following tasks for the FORUM:

- Spreading good practice and highlighting problems at Community level;

- Proposing, coordinating and evaluating harmonised enforcement projects and joint inspections;

- Coordinating exchange of inspectors;

- Identifying enforcement strategies, as well as minimum enforcement criteria;

- Developing working methods and tools of use to local inspectors;

- Developing an electronic information exchange procedure;

- Liaising with industry and other stakeholders, including relevant international organisations, as necessary.

One member from each Member State will be nominated to the Forum for a three-year period. 


\section{Introduction to the project}

Enforcement of EU legislation is the responsibility of the Member States. At an early stage, the Nordic countries identified a need to look into the REACH-proposal with the aim of examining its enforceability and as a basis for the forthcoming national work preparing for REACH enforcement.

In August 2004, the Nordic Council of Ministers granted funds to the project "Analysis of the enforcement according to REACH".

The objective of the project was to examine the REACH proposal of 29 October 2003 from an enforcement perspective. The project was to result in proposals on and viewpoints on how enforcement of REACH is to be carried out and organised, competence of inspectors, enforcement methods, need for co-operation between national enforcement authorities and between Member States. The results may also be used as an input to similar discussions in the CLEEN network ${ }^{1}$ and in the Forum. Where possible the project was to give input to the Nordic negotiators involved at EU Council level. However, during negotiations in the European Council there has been changes in the Commission proposal from 2003, but these changes have not been reflected in this project since they where published after the main analysis work was done.

The project was directed by Barbro Sillrén, National Chemicals Inspectorate, Sweden, with the assistance of:

Pia Petersen, Danish Environmental Protection Agency, Denmark

Annette Ekman, National Product Control Agency for Welfare and Health, Finland

Maren Wikheim, Norwegian Pollution Control Authority, Norway

The project and the interim results have been presented to:

- Nordic Product Register Group meeting in Uppsala, Sweden (October, 2004)

- Nordic Enforcement Group meeting, Oslo, Norway (May, 2005)

- Risk Reduction Division meeting at Swedish Chemical Inspectorate (June, 2005)

- Work Environment authorities meeting in Sweden (September, 2005)

- Regional authorities meeting at Swedish Chemical Inspectorate, Sweden (October, 2005)

- Nordic Workshop on REACH in Copenhagen, Denmark (December, 2005)

\footnotetext{
${ }^{1}$ Chemical Legislation European Enforcement Network, http://www.cleen-eu.net/
} 



\section{The content of the examination and working method}

The aim of the project was to examine and discuss the following Titles of REACH:

- Title II, Registration of substances

- Title VI, Evaluation of substances

- Title VII, Authorisation

- Title VIII, Restrictions on the manufacturing, marketing and use of certain dangerous substances and preparations

In addition and outside the scope of the study, the following Titles have been discussed briefly

- Title III, Data sharing and avoidance of unnecessary testing

- Title IV, Information in the supply chain

- Title V, Downstream Users

The project group has examined each Article under the titles of Registration, Evaluation, Authorisation and Restrictions with the purpose of answer the following questions:

- What tasks the enforcement authorities have to handle after REACH has entered into force?

- What information necessary for enforcement will be available according to the text of the Article?

- What additional information, if any, is needed to carry out the inspection?

- What competence and knowledge is needed for the inspection?

- What/which existing enforcement authorities may be affected by the REACH Regulation and what cooperation with other authorities is foreseen?

Comments with regard to interpretation of the Articles were forwarded to the Nordic negotiators in the European Council working group on REACH.

The aim was also to roughly visualize the main parts of enforcement of REACH in a Work Flow as a help for inspectors when planning and performing inspection activities at manufacturers and importers. 



\section{Title II Registration}

\subsection{Requirements in the REACH proposal}

There is a general obligation for manufacturers and importers of substances to submit a registration to the Agency for each substance manufactured or imported in quantities of $\geq 1$ tonne/year. If a registration is not submitted to the Agency it means that the substance is not allowed to be manufactured or imported. The REACH-proposal exempts certain substances that are regulated under other legislation, like medicinal products. Polymers are also exempted, but in some cases, monomers in polymers have to be registered.

The basic idea of registration is that manufacturers and importers of substances have to obtain information on the substances they manufacture or import, use this information to assess the risks arising from the uses and to ensure that the risks which the substances may present are properly managed.

Documents that have to be submitted with a registration are:

- A technical dossier and

- A chemical safety report, for substances in quantities of $\geq 10$ tonnes

The technical dossier should contain information on the properties, uses and on the classification of the substance as well as guidance on safe use. The information requirements depend on the tonnage in which the substance is manufactured or imported.

The chemical safety report (CSR) for substances manufactured or imported in quantities $\geq 10$ tonnes, should document the hazard classification of the substance and the assessment as to whether the substance is persistent, bioaccumulative and toxic (PBT) or very persistent and very bioaccumulative ( $\mathrm{vPvB}$ ). The CSR should also describe exposure scenarios for specific uses of substances classified as dangerous and for identified PBT and $\mathrm{vPvB}$ substances. The exposure scenarios should describe how substances are manufactured or used during their whole lifecycle and how the manufacturer or importer controls, or recommends to control exposure of humans and the environment. The exposure scenarios should include the appropriate risk management measures that, when properly implemented, ensure that the risks from the uses of the substances are adequately controlled. These scenarios should cover all identified uses and be included or should be annexed to the safety data sheet that will be supplied to downstream users. 
For certain isolated intermediates the registration requirements are less comprehensive. For intermediates that do not leave the site in which they are used, and those that are transported between sites under controlled conditions, only the hazard classification and any information on the properties of the substance that is already available to the registrants need to be submitted to the Agency.

To make the transition to the REACH system workable, the registration provisions will be applied in a step-wise fashion. For so-called "phase-in" substances a stepwise registration deadlines is established. Notified substances according to Directive 67/548/EEC are considered as registered and are called "non-phased-in" substances in the REACH proposal.

The Agency is responsible for managing all the registrations. About 30,000 phase-in substances are expected to be registered over the first 11 years when REACH enters into force, plus the "non-phase-in" substances. A completeness check of the content of the registration dossier will be performed by the Agency. The quality of submitted dossiers may be checked in the evaluation process.

A registrant may begin or continue to manufacture or import the substance within a set deadline if the registration is not rejected. It's important to note that this only implies that the documents comply with the registration requirements and is not a formal approval from the Agency.

There are specific rules for substances in articles. For substances that are classified as dangerous and are intended to be released from the article during normal and reasonably foreseeable conditions of use, a registration of the substance has to be submitted to the Agency. For substances that are not intended to be released, but may be released incidentally to the use of the article, a simple notification to the Agency is required if the substances are classified as dangerous. The volume thresholds are as for any substance manufactured in, or imported into, the EU and apply per article type. The registration deadline is 11 years plus 3 months after the entry into force of the Regulation.

\subsection{Comments}

It will be of crucial importance to enforcers to be able to identify substances for which a registration is needed. Knowledge of chemistry as well as process technology is needed, for instance with regard to intermediates and polymers/monomers. It was shown in a CLEEN project, $\mathrm{NONS}^{2}$, that manufacturer and importers had difficulties in providing enforcers with relevant documentation on substance identity.

\footnotetext{
${ }^{2}$ Notification of New Substances, http://www.cleen-eu.net/
} 
For substances outside the scope of REACH registration (Article 4.1), it is important that the company can show that the substance is only used for the described purposes. If not, a registration is needed!

There are many exemptions of varying degrees of clarity in the proposal. For example, in Article 4.2 the substances in Annex II and Annex III are exempted. Annex II is an example of a list with specified substances with both EINECS and CAS numbers. Therefore, it is foreseen that it will be rather easy to decide whether a substance is exempted or not. The exemptions in Annex III, which covers, among others, substances resulting from different chemical reactions and occurring in nature, will be more difficult for inspectors. There is no specific CAS or EINECS numbers given for the substances in this Annex III, which is why there will be questions and inquiries to Member States' help desks concerning these exemptions.

In Article 4.2.c, re-imported substances are exempted from registration in special cases. This is if the re-importer can show that the substance is the same as the one exported and that he has been provided with information in accordance with Articles 29 and 30 (and not Articles 30 and 31 as stated in the proposal). A key issue is what kind of documentation, in addition to the safety data sheet, the re-importer may be asked to provide to confirm re-importation of a registered substance and that he belongs to the same supply chain. A uniform approach in Europe is needed.

Active substances in plant protection and biocidal products should be regarded as registered according to Article 8, if they are included in annexes to the respective Directives. These Annexes comprise active substances approved for use in plant protection products and biocides. If a substance is used for other uses, a registration is necessary. There will be substances which are manufactured for uses only in PPP and biocides which will not appear on these annexes because they have not yet been approved in EU and consequently do not appear on the Annexes. One might ask whether these substances should be registered or not until they appear on the above mentioned annexes. From a REACH enforcement point of view it is essential that the Annexes to the Directives of plant protection products and biocidal products be updated frequently and available on a Commission or Agency website.

Definition, as well as interpretation, of an on-site isolated intermediate or a transported isolated intermediate might be difficult for inspectors. A registration should be submitted to the Agency and a registration number should be available. Guidance for inspectors will be needed clarifying the definitions of on-site isolated and transported isolated intermediates.

For product and process orientated research and development (PPORD) a notification should be submitted to the Agency. For inspection purposes, verification that a notification has been made and information on the decision taken including any conditions imposed, are needed. 
According to Article 7.9, information of the decision of the Agency should be kept confidential by the Agency and the Competent Authorities (CAs). If the inspectors don't have access to relevant information, they can't ensure that the conditions set have really been met by the company.

Polymers are exempted from registration but the non-registered monomers or other non-registered substances should be registered if the quantity for each of these substances and monomers is one tonne or more/year (Article 5.3). From this follows that if a monomer or another substance used in a polymer has already been registered by somebody else, then the manufacturer or importer of a polymer does not have to register the monomer or the other substance. This is not the same interpretation the Commission arrives at in document "Questions and Answers on REACH" Part II of 22.11.2004. The Commission answer (2.10.5) the question "Does that mean that any monomer already registered by someone is exempted from the registration obligation?":

- Any manufacturer or importer of a polymer shall submit a registration for the non-registered monomer substance(s). There is no exemption if someone else has already registered the same monomer".

Consequently Article 5.3 needs a clarification of duties as to when to register monomers and other substances used in polymers.

Substances in articles are to be registered if they are classified as dangerous, intended to be released and quantities are above $1 \mathrm{t} /$ year for each article type. Substances should be notified when, among other things, the release may adversely affect human health or the environment. Registration according to Article 19 should be carried out before the articles are manufactured or placed on the market, but there is no mention of when a notification should be submitted to the Agency.

With regard to articles, the Commission has given the following guidance in its document "Questions and Answers on REACH" Part II of 22.11.2004, 2.9.3:

- "If the substance is not on the C\&L inventory then the importer would have to evaluate if a substance is dangerous on the basis of available information. NB. There is no need for an importer to establish in general what substances are present in an article".

This raises the question of how the importer can comply with the requirements concerning articles without adequate knowledge about the substances present in the article. Experience has shown that companies have difficulties in getting the necessary information about articles which is required (Article 6) and as a consequence find it difficult to show adequate documentation to the inspector. 


\subsection{Tasks for enforcement related to this title}

In order to ensure that/carry out an inspection of whether the requirements of Title II Registration are complied with by the manufacturer and importer, the inspector should as a minimum check the following:

- That the substance is registered i.e. is there a registration number available, and does the tonnage manufactured or imported per year correspond to the tonnage level for the registration. If a registration number is missing the inspector needs to get documentation from the company in order to be able to decide whether a registration is required/necessary, whether an exemption applies or whether the substance is outside the scope of the registration

- That the substance is used according to the identified use in the registration

- That in cases where registration is above 10 tonnes/year CSA/CSR are performed with relevant information regarding exposure scenarios and risk reduction measures

If the substance hasn't been registered then the inspector should check and get verification for the decision:

- is the substance within the scope of the registration or not,

- is an exemption from registration according to Annexes II and III applicable for the substance

- is the substance only used in biocides and/or pesticides and whether the substance appears in the relevant Annex

- is a PPORD notification relevant for the substance. If so the inspector has to check that the substance has a notification number and that the conditions set in the PPORD decision from the Agency are met

- Whether a phased-in registration is applicable and that a preregistration has been made for the substance

A specific challenge for inspectors will be to get information about substances in unclassified preparations as well as unclassified substances in classified products. Enforcement experience has shown that many companies (mostly importers) can only get information on the content of hazardous substances and not the complete/total composition of the preparation.

Companies formulating preparations often consider themselves as downstream users failing to consider that they may instead be manufacturers of substances for which the obligation to register must be considered. A good knowledge of chemistry is therefore needed both by companies and enforcement authorities. 


\subsection{Conclusions from examination of Title II}

- A big challenge which REACH poses for enforcers will be concluding whether the substance needs to be registered or if it is outside the scope of REACH or covered by any of the many exemptions. This requires knowledge of the other EC legislation mentioned in REACH as well as general knowledge of chemistry and process technology.

- Registration and notification of substances in articles will be difficult to enforce. To get information on substances incorporated in articles from manufacturers and importers might be difficult.

- Enforcement of conditions set for the PPORD exemption will not be possible unless the conditions are revealed to enforcement authorities.

- Inspection of Downstream Users who are manufacturers of substances will need special competences from enforcers.

- Inspectorates/enforcement authorities need guidance on interpretation of the Regulations and guidance on substance identity, exemptions and definitions. This guidance could be in the form of a Manual of Decisions but a National Help Desks or help at EU-level could also contribute with valuable information.

- Specific knowledge is needed for enforcement of registration of monomers and other substances in polymers.

- Up-to-date information on the active substances in biocides and pesticides which are exempted from the REACH registration duty must be accessible to enforcers.

- A decision is needed on what information enforcement authorities will have access to from the Agency's database and how. Enforcement authorities' access to information in the Agency databases must be made clear.

- Enforcement of this Title will involve several national enforcement authorities. As a consequence cooperation at national level between authorities is crucial. 


\section{Title III Data sharing and avoidance of unnecessary testing}

\subsection{Requirements in the REACH proposal}

This title sets out rules regarding data sharing in order to reduce testing on vertebrate animals and reducing costs to industry. Data gained by animal testing are to be shared. A system/process (the pre-registration and SIEF) will be set up to enable and encourage manufacturers and importers of the same substance to find each other, get an overview of available studies on vertebrate animals and to reach agreement on data sharing of the studies.

Pre registration has also to be done in order for companies to benefit from registration deadlines (Article 21). If companies do not pre-register their substances they have to register the substances immediately.

\subsection{Comments}

Pre-registration is a prerequisite in order to benefit from the transitional regime concerning registration of phase-in substances including CMRs. For enforcement it is essential to remember that if a registrant does not pre-register, he has to register the substance sixty days after entry into force of the Regulation (Article 137.2).

Article 26.2 contains no explicit duty to pre-register CMR-substances. Hence CMR substances could never benefit from the transitional provisions for registration unless they were phase-in substances and were registered according to Article 21.

\subsection{Tasks for enforcement related to this title}

In order to ensure that the requirements in relation to Title III are complied with by the manufacturer and importer, the inspector needs to check:

- that the phase-in substance is pre-registered. If not it has to be registered. If it is not pre-registered or registered the manufacture and/or import of the substance will be prohibited in accordance with Article 19. For the inspector it is essential to have access to "a database" with up-dated information on the pre-registration status for 
phase-in substances. In the present proposal such information is not to be included in the database(s) which will be maintained by the Agency (Article 73).

\subsection{Conclusions from examination of Title III}

Conclusions from examination of Title III, Data sharing and avoidance of unnecessary testing:

- Phase-in substances not pre-registered in accordance with the timelimits in Article 26.2 are to be registered sixty days after entry into force.

- Article 26.2 doesn't mention any deadline for pre-registration of phase-in substances classified as CMRs above 1 tonne

- Proof of pre-registration status has to be shown by the company for substances within the scope of registration. Information on preregistered substances is needed from the Agency. 


\section{Title IV Information in the supply chain}

\subsection{Requirements in the REACH proposal}

REACH should ensure that not only manufacturers and importers have the information they need to use chemicals safely. This information should also be communicated to their customers, i.e. downstream users and distributors. Information relating to health, safety and environmental properties, risks and risk management measures are to be communicated both down and up the supply chain, and between all actors within the same supply chain.

The provisions of the current Safety Data Sheets Directive (91/155/EEC) are carried over into the REACH Regulation, and the safety data sheet (SDS) is meant to be the main tool for information in the supply chain. REACH will collect more information as a result of registration, so there should presumably be more data for improvement of the quality of the SDS.

When exposure scenarios are to be performed according to registration requirements, relevant scenarios are to be annexed to the SDS and communicated down the supply chain. New information on hazardous properties as well as information that might call into question the appropriateness of risk management measures identified in the SDS is to be passed up the supply chain.

Information on registration number, authorisation and restriction is, for substances for which a SDS is not required, to be sent in writing down the supply chain.

\subsection{Comments}

Inspection of safety data sheets (SDS) has been carried out for many years in the Nordic countries. As the current Directive (91/155/EEC) is incorporated in the REACH proposal, the same questions concerning enforceability will probably arise in the future, when REACH enters into force, e.g. inconsistencies in the SDS, poor correlation between SDS and label, same information given for first aid measures regardless the classification of the preparation. The ECLIPS project under the umbrella of the CLEEN Network concluded that only $30 \%$ of SDS's comply with the legislation. For further information on this project, see http://www.cleeneu.net. 
Article 29.1 states that SDS's should be supplied by a person responsible for placing a substance or preparation on the market. A "harmonised" interpretation of the definition of placing on the market is crucial from an enforcement point of view for example when requesting that an amendment of the SDS be made.

The language of the SDS should be the official languages of the MS in which the substance/preparation is placed on the market, if the DU so requests. Today the SDS is to be submitted in the official languages of the Nordic countries where the chemical is placed on the market. Unless this requirement for national language is taken onboard in the REACH Regulation the result will be deterioration in the current rules. The same comment is also valid for CSA's, CSR's and ES's because these documents will be examined by national inspectors and some of them will also be addressed to Downstream Users.

For substances for which a SDS is not required, the inspector may ask for written documentation on registration number, valid authorisation and restriction imposed, because, in accordance with Article 30, this information is to be sent down the supply chain.

Article 31 obligates any actor in the supply chain to communicate certain information to the next actor or distributor up the supply chain. However, no special format is required. The means and need to enforce this communication duty remains unclear. For instance: what constitutes proof of communication?

According to Article 33, all actors in the supply chain must assemble and keep available all information they require to carry out their duties for a period of at least 10 years after they last manufactured, imported, supplied or used the substance/preparation. This information should upon request be made available to any $\mathrm{CA}$ in which that actor in the supply chain is established or to the Agency. Whether enforcement authorities belong to these CA's is not clear in the REACH proposal. It is essential that enforcement authorities/inspectorates also have access to relevant information in the Agency database.

\subsection{Tasks for enforcement related to this title}

In order to enforce the requirements in relation to this title the inspector needs to check:

- That SDS and/or other requested information is communicated up and down the supply chain

- The information contained in the SDS and that it correlates with the information shown on the label 
- That the substance is handled and used according to the exposure scenarios submitted and that relevant risk reduction measures are being applied

- The requirement to report new uses outside the identified uses and different classification of substances could enable competent authorities to evaluate if the substances reported give rise to concern or if there is a need to take appropriate measures according to Annex XIV.

- That a safety data sheet (SDS) when required is available. In cases where registration is above 10 tonnes/year that the information in the SDS is consistent with the information in the CSA/CSR, exposure scenarios prepared and annexed for identified uses and risk reduction measures followed and complied with.

\subsection{Conclusions from examination of Title IV}

- Guidance on verification of the duty to communicate information in the supply chain according to Article 30 and 31 is needed

- Enforcement authorities are not specifically mentioned in Article 33 as recipients/receivers of information from actors in the supply chain and must be incorporated.

- The language requirements of SDS, CSA, CSR and ES have to be prescribed in the Regulation

- Cooperation with other inspection authorities both nationally and within EU is crucial 



\section{Title V Downstream users}

\subsection{Requirements in the REACH proposal}

REACH presents an opportunity for downstream users (DU) to provide information to assist in the preparation of a registration (Article 34).

If a DU wants to make his use known, he must write to the manufacturer, importer or DU who supplies him with the substance and provide sufficient information so that his supplier can prepare an exposure scenario for this use in his CSA. For registered substances the manufacturer or importer must comply with the obligation in Article 13 to perform a CSA/CSR for substances in quantities $\geq 10$ tonne/year before he next supplies the substance to the DU making the request and for phase-in substances before the relevant transitional deadline in Article 21 for registration.

If the DU chooses not to make his use known to his supplier or if the supplier does not include the use as an identified use, the DU has to:

- Prepare a CSR (should be kept available and up to date) for any use outside the conditions in an exposure scenario communicated to him in a SDS

\section{but only if}

- a SDS is required to be communicated with the substance;

- a CSR is required to be completed by his supplier ( $\geq 10$ tonnes/year)

The DU need not prepare a CSR himself if he implements or recommends an exposure scenario which includes as a minimum the conditions described in the exposure scenario communicated to him.

Another obligation for the DU is to report to the Agency if he uses a substance (in quantities of 1 tonne or more per year) outside the conditions described in an exposure scenario communicated to him with the SDS. He should also report to the Agency if his classification of a substance is different to that of his supplier. Information reported should be updated if there is any change in the earlier reported information.

A DU must identify, apply and (if suitable) recommend appropriate measures to adequately control identified risks, on the basis of the SDS supplied to him or from his own CSA.

The DU must comply with the requirements in Article 34 after 12 months and in Article 35 after 6 months after receiving the registration number communicated to him in the safety data sheet (Article 36 ). 


\subsection{Comments}

Companies considering themselves as downstream user may not necessarily be considered a Downstream User according to REACH. Many companies can act as importers and even manufacturers in relation to REACH.

Downstream users cover a wide range of actors from formulators of bulk chemicals used in industrial processes to formulators of final preparations (e.g. cleaning products) used by other downstream users such as industrial users, professional users, re-importers and/or re-fillers. To identify the roles under REACH and determine what requirements are relevant will be challenging for both the actors themselves and for enforcement authorities. A guidance document for requirements on downstream users is required.

A challenge for enforcement authorities will be to control whether a company's use of a substance is covered by the identified use or whether any use outside the identified use has been reported either up the supply chain or to the Agency. The enforcement activity might also comprise of control of application of adequate risk reduction measures specified in the SDS or in the exposure scenarios.

It would probably be difficult for the manufacturer or importer to get information on all kind of use of "his" substance as one specific substance could have up to 20000 different customers/users. This will place great demands on downstream users to communicate information up the supply chain. It will also mean that it could be difficult for inspectors to decide whether the use found at an inspection is covered by the identified use (there is a need for guidance).

According to Article 35 (4) a DU should report to the Agency if his classification of a substance is different to that of his supplier. How the Agency is to handle such reports is not described. Neither is it clear how the national inspection authorities are to follow up on the different hazard classifications of a given substance.

The requirement to report uses outside the identified uses and different classifications of a substance could enable competent authorities to evaluate whether the substances reported give rise to concern or if there is a need to take appropriate measures according to Annex XIV.

Verification and evaluation of CSA/ES cover aspects of health, environmental and safety issues and require comprehensive competencies by the inspectors. This will need cooperation between different enforcement authorities with different competencies, both nationally and within EU. 


\subsection{Tasks for enforcement related to this title}

- check exposure scenarios annexed to the SDS and verify the consistency of this information based upon CSA/CSR (i.e. appropriate risk reduction measures (RRM))

a) this information is either given by the supplier or prepared by the DU himself in his CSA

- clarify whether a use is included or not in the "intended" use

a) If not - should this be reported to CA and/or the Agency? Or should the use be regarded as forbidden?

- check and verify that information in CSR and SDS is updated

- verification that information of own use and classification has been reported to Agency above 1 tonne (Article 35) if relevant

a) compare hazard classification made by DU to classification in the inventory list. In case of divergence, guidelines on further reporting process to CA or the Agency is needed.

- check deadlines for reporting own use to supplier or to the Agency (Article 36)

\subsection{Conclusions from examination of Title $\mathrm{V}$}

Downstream users are a group of very different kinds of companies with different knowledge and business activities. Some companies considering themselves as downstream users may however be manufacturers and/or importers according to REACH.

- Inspection of downstream users should also include requirements related to restriction, authorisations and quality of SDS \& classification/labelling

- Guidance is needed on how a downstream user verifies that information has been reported to his suppliers or the Agency and what the response has been.

a) i.e. duties of all actors in the supply chain have to be very clear. There could be problems if a distributor delivers the substance and the SDS. According to Article 34, a distributor has no obligation to receive information from a downstream user about new uses outside the identified use. As the concept "supplier" is not defined, it is also unclear whether the distributor has any obligation to communicate information down the supply chain for substances and preparations that do not require a SDS (Article 30.2).

- There is a need for a more precise definition or clarification of "use" versus "intended use"

a) Practical guidelines needed (could be branch specific) 
- Guidance is needed on how to handle/report self-classification of substances (and preparations) when there is divergence between actors in the supply chain

- Inspectors need sufficient and adequate competencies. Sometimes even specific trade/branch competencies are necessary and knowledge of use of substances/preparations

- Processes to ensure feedback from enforcement must be established at least at national level but also in relation to the Agency/Forum 


\section{Title VI Evaluation of substances}

\subsection{Requirements in the REACH proposal}

REACH proposes two types of evaluation to be carried out by the Competent Authorities:

- Dossier evaluation - is a compliance check of the registration dossier and an evaluation of any testing proposals made by the registrant. It is not a formal approval; it only implies that the documents comply with the registration requirements. This evaluation may lead to decisions on information needed to bring the registration into compliance with the requirements and decisions to carry out tests.

- Substance evaluation - for substances suspected of causing a risk to health or the environment at EU level, further information from industry may be requested.

The evaluation process does not cover every substance or registration dossier but may lead to actions to be taken under the authorisation or restriction procedures.

\subsection{Comments}

The requirements under this title are addressed to national competent authorities evaluating the information submitted in connection with registration. The compliance with these requirements needs no action from enforcement authorities.

However, Articles 48.2 and 48.3 states that if a registrant has ceased the manufacture or import of the registered substance his registration is no longer valid. When or if this is the case, there will be substances as such, in preparations and in articles on the market with registration numbers that are no longer valid. There are no requirements concerning the registrant's duty to withdraw such a substance (on its own, in a preparation or in an article) from the market or any transitional period for these cases. 


\subsection{Tasks for enforcement related to this title}

No specific tasks relating to enforcement in this title.

\subsection{Conclusions from examination of Title VI}

- Guidance is needed on how to handle substances with registration numbers that are "no longer valid"

- Access to information in Agency's database concerning substances with registration numbers that are "no longer valid"

- Feedback from enforcement authorities to national CA, especially when finding differences between evaluated information and reality, e.g. risk reduction measures applied, classification, tonnage. Article 43a. How to supply and to whom? 


\section{Title VII Authorisation}

\subsection{Requirements in the REACH proposal}

In order to ensure that the risks from substances of very high concern are properly controlled or substituted, REACH proposes an authorisation procedure. Substances of very high concern (SVHC) are defined as:

- Carcinogenic, mutagenic or toxic for reproduction (CMRs), category 1 and 2

- Persistent, bioaccumulative and toxic or very persistent and very bioaccumulative (PBTs/vPvBs), or

- Substances, which do not fulfil the criteria for the above mentioned effects but are identified as causing serious and irreversible effects to humans or the environment equivalent to those mentioned above, such as endocrine disrupters, on a case-by-case basis.

SVHC will step by step be included in Annex XIII to REACH. Once included in this Annex, the use(s) and placing on the market need to be authorised before a specific date, the sunset date. Unless authorised it will be prohibited to place the substance on the market or use it on its own, in a preparation or to incorporate it into an article. For substances already placed on the market the Regulation requires manufacturers, importers or downstream users, who wish to continue to use the substance or place it on the market after the sunset date, to send an application for authorisation to the Agency at least 18 months before the sunset date.

An authorisation should specify:

- The person(s) to whom the authorisation is granted;

- The identity of the substance(s);

- The use(s) for which the authorisation is granted;

- Any review period;

- Any monitoring arrangement

The authorisation is normally subject to a time-limit and the holder must ensure that the level of exposure is reduced to as low as is technically possible. Holders of an authorisation will obtain an authorisation number which must be included on the label before the substance is placed on the market for an authorised use.

There are uses, that are exempted from the authorisation e.g. uses in plant protection and biocidal products. Exempted are also substances in 
preparations when the concentration of the substance is below $0,1 \%$ or under the concentration limit which result in the classification of the preparation as dangerous.

If a downstream user does not have an authorisation for his own use he may use the substance provided he obtain the substance from a supplier to whom an authorisation has been granted and provided that his use is in accordance with the conditions of that authorisation. All such downstream users must notify their use of an authorised substance to the Agency within 3 months of the first supply of the substance.

\subsection{Comments}

In order to control

- that an application for an authorisation for a substance on Annex XIII has been sent to the Agency or

- that an authorisation has been granted for placing on the market an Annex XIII substance for a use(s)

there will be time limits (sunset date in Annex XIII and review periods in the authorisation) to check and if an authorisation is granted, various conditions (e.g. monitoring of emissions and exposure) to control. This is an area where many national enforcement authorities will be involved.

When an authorisation is granted, it is given to a person or persons. This indicates that it could be both a physical and a legal person that can be a holder of an authorisation. Definition of person/persons would make this clearer.

A central part of the authorisation is the conditions set for the specific uses of the substance. For enforcement authorities it is essential that the authorisation in a clear and understandable way describes the uses and different conditions applicable to the authorisation. Otherwise it could be difficult to decide whether a company complies with the authorisation granted. It is worth noting that the precise use of a substance is confidential information according to Article 116.2.b.

The holder of an authorisation must include the authorisation number on the label before placing the substance on the market for an authorised use. This labelling requirement does not, however, seem to apply to preparations and articles.

It is not clear if one substance can have more than one authorisation number depending on the holder of the authorisation neither is it clear whether there will be different authorisation numbers for different uses of the same substance (see Articles 57.7 and 62).

A subsequent applicant for an authorisation can refer, by a letter of access, to parts of a previous application according to Article 60. If this is 
done, will the subsequent applicant get another authorisation number or the same as the first applicant?

It follows from the above that the authorisation number is the tool for enforcers to ensure that the substance is handled within the same supply chain and that is why the Regulation has to be very clear about to whom, to what substances and to what uses the authorisation number is given.

For enforcement purposes it should be noted that the authorisation does not concern import of substances in preparations or incorporated in articles.

A challenge for enforcement of this title will be the exemptions, e.g.:

- a challenge may be substances subject to authorisation which are waste and are being re-used. Knowledge of Directives relating to waste is needed for enforcement purposes.

- whatever substance, not only the active substances, used in plant protections products and biocidal products, as medicinal products for human or veterinary use, as food additives, as additives in animal feeding stuffs, as flavouring in foodstuffs, as on-site isolated intermediate or as a transported isolated intermediate, as motor fuels, as fuel in mobile or fixed combustion plants of mineral oil products and use as fuels in closed systems are exempted. Import of substances on Annex XIII used for/as the above mentioned purposes are thus exempted from authorisation. Consideration of relevant documentation is needed and is of special relevance for enforcement.

- substances subject to authorisation and used in cosmetic products and in food contact materials are exempted from authorisation only if the substances are identified because of the hazards to human health. If the substances are listed on Annex XIII and meet the criteria for PBT or $\mathrm{vPvB}$ they have to be authorised for use in cosmetic products and in food contact materials. Enforcement of this necessitates cooperation between national enforcement authorities.

- use of substances in preparations below a specified limit (e.g. classification limit or $<0,1 \%$, see Article 53.7) does not need an authorisation. It is essential that enforcement authorities have access to reliable information on the composition of the preparation.

Feedback from enforcement authorities could be used when authorisations are being reviewed. Feedback could comprise information such as actual use of the substance, are conditions complied with or are they even possible to comply with and results of monitoring. For substances, that may be included in Annex XIII some background information on uses could be given from enforcement results. Feedback should be given to the national Competent Authority. 
It is extremely important that the inspectors have access to relevant information in the Agency's database. The database must be updated so that the inspector can check e.g. substances authorisation numbers and time-limits for submission of a new application for an authorisation. Of importance is that the database contains the information specified in Article 57.7. If this information is only available on request it would prolong the enforcement activities.

\subsection{Tasks for enforcement related to this title}

The requirement for authorisation of substances will result in new tasks for the enforcement authorities and co-operation between different national authorities will be needed.

In order to control that the requirements in relation to Title VII are complied with, the inspector needs to check:

- is the substance on Annex XIII?

- is there an applicable exemption for the use of the substance (Article $53,3-7)$ ?

- is there an authorisation granted for that particular use of the substance?

- that the conditions set have been followed

- that the time limits (sunset dates and review periods) related to the authorisation are complied with

- that the substance is labelled with the authorisation number by the holder of authorisation

- that a downstream user uses the substance in accordance with the conditions of an authorisation granted to an actor up the supply chain and that the downstream user has notified his use of the substance to the Agency

\subsection{Conclusions from examination of Title VII}

- It is important that the definitions of placing on the market and identified uses as well as the exemptions and content of conditions set are described in a clear manner, so it is possible to decide whether a company is in compliance with the requirements or not. Guidance will probably be needed in many cases.

- Some of the information needed to conclude whether a use of a substance is in accordance with an authorisation granted is considered as confidential e.g. links in the supply chain and the specific use of a substance (Article 116.2). It is important for enforcement authorities to have access to relevant information in the Agency's database. 
- Enforcement will involve several national authorities. National legislation concerning the responsible enforcement authorities and their responsibilities must be defined and cooperation/network between the authorities has to be in place when REACH enters into force.

- Feedback from enforcement authorities to national CA's on inspection activities and results from them could be valuable e.g. if a company does not comply with the conditions of the authorisation. This could be a part of the report that must be submitted to the Agency every year according to Article 124. 



\section{Title VIII Restrictions on the manufacturing, marketing and use of certain dangerous substances and preparations}

\subsection{Requirements in the REACH proposal}

The title sets out general provisions for when a substance on its own, in a preparation or in an article must not be manufactured, placed on the market or used unless it complies with conditions given for that substance, for which Annex XVI contains a restriction. The restrictions procedure regulates conditions for any of these activities.

Today no general exemptions exist for scientific research and development and for product and process orientated research and development in the restriction Directive (76/769/EEC). This is changed as in REACH exemptions are to be given for substances not exceeding 1 tonne/year.

The existing restrictions in Directive 76/769/EEC including later amendments (such as the ban on asbestos and restrictions on the uses of cadmium and certain azo-dyes) are carried over into REACH. Annex XVI contains a consolidated version of all current restrictions. The future Directive of persistent organic pollutants (POPs) is carried over (Annex XVII) with exemptions for use of a substance for laboratory scale research and as a reference standard.

Substances which are waste and fall within the scope of Directive 75/442/EEC are not subject to restrictions.

Any substance on its own, in a preparation or in an article may be subject to restrictions if it is demonstrated that risks are not adequately controlled at European level.

New proposals for restrictions may be prepared by Member States or the Agency. The proposal should demonstrate that there is a risk to human health or the environment which needs to be addressed at European level. The restriction procedure shall act as a safety net in REACH.

\subsection{Comments}

Title VIII is an implementation of current legislation for restrictions under Directive 76/769/EEC. Lessons learned from enforcement of these restrictions will be useful in the future. Any new "problems"/duties for 
enforcement are however not foreseen. Experience is that the legislative text is sometimes not unambiguous and that necessary standards and/or methods for analysis are missing. Experience and results from CLEEN projects, (e.g. EuroCad) indicate differences in interpretation and enforcement practice between Member States regarding bordering legislation, such as cosmetics, food contact materials, toys etc. Consequently, there is a need for co-operation between different national enforcement authorities and inspection bodies e.g. consumer, food, working environment, and custom authorities.

Enforcement experience shows that there are problems in getting information on complete compositions of preparations. Restrictions concerning articles have shown the same problems.

Enforcement of exemptions of substances used in SR\&D and PPORD needs verification of the 1 tonne/year quantity and the SR\&D or PPORD activity. Guidance would be useful to enforcers on what may be considered SR\&D or PPORD activity.

Dossiers concerning this title, including restrictions suggested, must be made publicly available on the Agency's website. The Agency will invite all interested parties to submit comments. It would be valuable if enforcement authorities were involved in giving comments or feedback to improve the enforceability of new restrictions.

\subsection{Tasks for enforcement related to this title}

In order to ensure that the requirements in relation to Title VIII are complied with by the manufacturer, importer and the downstream user when marketing or using a substance on its own, in a preparation or in an article, the inspector need to check:

- Is there a restriction applicable for the substance in Annex XVI or XVII

- Is the use of the substance in compliance with any such restriction

- verification of tonnage for SR\&D or PPORD activity

\subsection{Conclusions from examination of title VIII}

- It is important that the description of the restriction in question is clear i.e. what does the restriction cover, are there any exemptions from the general restriction and does the restriction impose specific conditions.

- It is crucial to get access to sufficient and adequate information on the composition of a preparation or an article

- similar interpretations of placing on the market among enforcers in the different Member States is needed 
- There is a need for clarification or guidance if the Restrictions in REACH also cover articles that can be considered as toys or medical devices.

- Need for co-operation with other enforcement authorities at national level

- Comments from enforcement authorities on proposals for new restrictions may have an added value for future enforcement. 



\section{Title XIII Enforcement}

Enforcement is carried out at national level and it is a duty for the Member State to have and maintain a system of official controls and other activities according to Article 118, as it is today.

It is also a national duty for the Member States to lay down provisions on penalties applicable for infringement of the provisions of present Regulation and to take all measures necessary to ensure that they are implemented. Penalties provided for must be effective, proportionate and dissuasive.

Member State are to submit a report to the Agency by 1 July each year on results of the official checks, monitoring carried out, fines set and other measures taken pursuant to Article 122 and 123 during previous calendar year. The Agency will make these reports available to Commission.

\subsection{Comments}

The national provisions on penalties and any consequences for any adjustment or new national legislation have to be in place when REACH enters into force. This is important for the purposes of educating inspectors in the enforcement authorities, and with regard to informing and educating national companies.

Even if it is stated that the penalties must be effective, proportionate and dissuasive, they will never be harmonised, as decisions will be made at national level.

There is no requirement as to the format or language of the annual report. It will probably be an administrative task to compile the report and many national enforcement authorities could be involved in this task. This indicates that guidelines are needed if the Agency is to have any chance of evaluating the reports. It could be a task for FORUM to develop a format and specify what information is considered important to include in the report (e.g. whether it should be quantitative or qualitative).

\subsection{Tasks for enforcement related to this title}

No specific tasks to enforce in this title. 


\subsection{Conclusions from examination of Title XIII}

- There is no specified format or requirement as to language of the annual report to the Agency

- Organisation/structure of national enforcement has to be in place when REACH enters into force as well as any national legislation e.g. with regard to penalties and sanctions

- Feedback from enforcement activities could be given in the annual report. 


\section{Development of a guideline for inspection of manufacturer/ importer}

Annexed to this report is a flow chart/guideline. The flow chart (guideline) is meant to be seen as a thought starter and a help when planning REACH projects in future. It should preferably be used electronically: in the "work flow inspection" document there are links to checklists in some of the boxes. It is important to note that these checklists should not be seen as complete, they should just be examples of questions/check points for inspectors. For any future project, the checklists may have to be modified and redesigned to fit that project.

This is one way to create a guideline and especially of visualising the work flow electronically. It should be noted that each MS and each project has to create its own guidelines/checklist and may use these guidelines as a help if desired.

The guideline is, as mentioned above, not "ready-to-use" and some parts are missing e.g. the downstream users. Not all parts of REACH have been analysed in this project and that is why the guideline is incomplete. Neither is the flow of documents that companies have to send to (or receive from) the Agency/CA included in this guideline, as this has not been seen as an inspection activity in this project. 



\section{Conclusions and Discussion}

Enforcement of REACH will be a national responsibility and it is important that national legislation is in place before REACH enters into force e.g. provisions on penalties, sanctions or any other adjustment in present legislation. This is important not only for enforcement in general but also with regard to informing and educating both companies and the authorities that are to enforce REACH.

Organisation of the national enforcement authorities might also need to be considered and if necessary, reorganised so as to be efficient for REACH enforcement. Enforcement of REACH will involve several national authorities such as Customs Authorities, Occupational \& Health Authorities, Chemical Inspectorates, Environmental Protection Agency, Consumer Protection Agencies, Food safety Agencies as well as corresponding authorities at regional and local levels.

$\mathrm{REACH}$ brings with it a strong need for cooperation between national enforcement authorities as well as enforcement authorities in other MS. Taking into account the different authorities involved in the enforcement of REACH at national level and the fact that Member States will have only one representative in the FORUM, there is a need to establish a national network in order to coordinate national input to the FORUM and to ensure the flow of information to responsible national authorities.

What types of enforcement actions are needed to make REACH work must be further analysed. Nothing is mentioned in the REACH Regulation about which Articles are expected to be enforced or to what extent and on what level. According to document "Questions and Answers on REACH" Part II of 22.11.2004, the Commissions answer to the question "What types of enforcement mechanisms has the Commission considered when developing REACH?":

- "REACH has been designed keeping both the expected competences of actors and enforcement needs in mind. It is expected that actors down the supply chain, in particular in smaller enterprises, have a competence in risk management (this is required by current legislation), but not necessarily in risk assessment. This is also case for inspectors. The know-how regarding the hazards and potential risks of chemicals generally lies with the manufacturers and importers and with the national agencies/authorities. The exposure scenarios are the conditions of use, including risk management measures, which, when implemented, can ensure safe handling and use of the substance. It therefore is built up of element which the local risk managers down the supply chain understand and can apply. They are also enforceable 
by inspectors as they are formulated in risk management terms, not requiring any deep knowledge of toxicology from the inspector. The inspector therefore will be able to check if the exposure scenario listed in the CSR/SDS or the CSR developed by the DU in fact is implemented. The national agencies have full access to this information and they can check if the emissions generated by applying the exposure scenario are sufficiently low. This concept is more easily enforceable and provides better protection than does the current legislation".

This answer from the Commission does not indicate that inspectors are meant to control e.g.:

- that manufacturers/importers register their substances

- information demands

- product information such as safety data sheet and labelling

- whether information in a safety data sheet is in accordance with CSA/CSR

The Commissions answer only points out that the work environment conditions are important to control, not that substances are registered or all the information in the supply chain (up and down), and the quality of that information, which is the base for a good work environment. Relevant and reliable information in the supply chain is a purpose of REACH as REACH is to gather data that is to be transformed into information that will result in a safe use of chemicals. An efficient enforcement of regulations as to information will contribute to better information and in the end a safer use of chemicals.

It is extremely important that the inspectors have access to relevant information in the Agency's database. The database must be updated so that the inspector can check relevant information for the inspection. If information is only available on request it would prolong the enforcement activities.

In the proposed Regulation there are requirements with regard to different kinds of documentation/information. In some cases, no mention is made of the specific format of the information/documentation (e.g. information up the supply chain (Article 31) and information down the supply chain when no SDS is required (Article 30)). Neither is there any requirement as to language in the information/documentation which is why there could be problems in understanding the document/information both for national enforcement authorities and other recipients.

Enforcement is necessary and important, this has been the common opinion throughout the drafting phase of REACH. How and who will enforce REACH is said to be a national task, but it must be outlined what is the responsibility of national enforcement and where the Agency/CA 
"takes over". E.g. should enforcement authorities examine CSR and CSA, should they examine divergences in the inventory list or should they demand correction if it appears that already evaluated information is incorrect? There are some borderlines that have to be identified and made clear.

With REACH there will be a need of different competences/knowledge for enforcers e.g. chemistry, toxicology, ecotoxicology, risk management measures, knowledge of exposure scenarios, bordering legislation, how to consult Agency's database, product knowledge etc. Cooperation with regard to exchange of competences within the authorities and between authorities is therefore necessary and education/broadening of the inspectors own competencies may be needed.

When REACH enters into force there will probably be much discussion of interpretation e.g. placing on the market, substance identity, exemptions, definitions, use and conditions, how to handle registration numbers that are "no longer valid". Therefore some kind of help desk or guidance could be useful. This could be arranged by the Forum or the Agency in order to provide similar guidance for all MS.

Feedback from enforcement activities could be used as an important source of information on how the Regulation works. The results can give a good insight on e.g. how substances/preparations are used, whether conditions are being met or whether they are written in a way that is impossible to comply with, how differences in the inventory list is dealt with between companies and how this works in reality. Experience gained from enforcement e.g. discovered hazards to workers or consumers can also provide arguments when proposing harmonised classification, candidates for authorisation or restriction. The question of how to supply feedback from enforcement has to be further investigated.

Downstream Users are a very varied collection of companies, from formulators and down to end users, and a large part of the companies will be affected by REACH. This project has not analysed in depth enforcement of REACH for these companies. Due to the fact that the Nordic Countries have mostly Downstream Users, it could be of interest to further analyse the situation of enforcement for Downstream Users. 



\section{Sammanfattning (Swedish summary)}

Europeiska kommissionen föreslog den 29 oktober 2003 en ny kemikalielagstiftning rörande registrering, evaluering, auktorisation och begränsningar av kemikalier (REACH). Därefter har kommissionen startat ett flertal projekt då det gäller implementering av REACH, s.k. RIP-projekt, med ambitionen att utveckla vägledande dokument för industri och myndigheter. Inga av dessa inkluderar dock någon utarbetning av vägledning för tillsyn.

Nordiska Ministerrådet beviljade i augusti 2004 projektmedel för att starta ett gemensamt nordiskt projekt om "Analys av tillsyn enligt REACH”. Målsättningen med projektet var att granska huvuddelarna (registrering, evaluering, auktorisation och begränsningar) i förslaget till ny europeisk kemikalielagstiftning (REACH) ur ett tillsynsperspektiv. Granskningen skulle bl.a. leda till förslag och synpunkten på hur REACH kan komma att påverka tillsynen genom de hinder och möjligheter som uppstår genom lagtextens formulering, nya krav på tillsynsmyndigheter, förändrade tillsynsmetoder och nya samarbetsformer mellan myndigheter och medlemsstater. Resultatet av projektet var också tänkt att kunna användas $\mathrm{i}$ det fortsatta tillsynssamarbetet $\mathrm{i}$ Norden som $\mathrm{i}$ det pågående (CLEEN) och i det kommande (FORUM) inom EU. Syftet var också att kunna ge underlag till de nordiska länderna i förhandlingsprocessen. Det har dock varit ändringar i lagförslaget från 2003, men de ändringarna har inte beaktats i detta projekt då de publicerades efter att granskningen var gjord.

Baserat på det nordiska projektet har Sverige i samarbete med de övriga nordiska länderna föreslagit ett Europeiskt tillsynsprojekt om REACH. Förslaget presenterades i mars 2006 på ett möte i Commission Working Group (CWG) om REACH, där det också beslutades att genomföra projektet. På samma möte utsågs en subgrupp under CWG (s.k. PreForum) att organisera och starta upp arbetet i det kommande Forum.

Artikel 122 i REACH anger att medlemsstaterna ska ha ett system för kontroller och annan verksamhet som är lämplig med hänsyn till omständigheterna. Påföljder vid överträdelser av bestämmelserna ska fastställas och erforderliga åtgärder för att se till att de verkställs ska vidtas. Några mer specificerade villkor eller krav på tillsynen eller några uppgifter för tillsynsmyndigheter innehåller dock inte REACH.

Ett Forum för tillsyn kommer att organiseras under Europeiska kemikaliemyndigheten. Forum ska bl.a. att samordna tillsynsprojekt och gemensamma inspektioner. En annan uppgift är att utveckla arbetsmetoder 
och verktyg för inspektörer. Det finns dock inget nämnt i REACH om någon "help desk" för tillsynsmyndigheter, men om tillsynen ska bli så harmoniserad som möjligt bedöms det vara av stor vikt med vägledning och tolkning för tillsynsmyndigheter.

REACH betyder nya utmaningar för tillsyn i medlemsstaterna. Det kommer att vara nödvändigt att utbilda inspektörer och öka kunskapen om den nya förordningen och de nya tillsynsuppgifterna. Ett fungerande samarbete mellan olika tillsynsmyndigheter behöver upparbetas på nationell nivå liksom en effektiv tillsynsorganisation för att få REACH att fungera i praktiken. Eftersom varje medlemsstat bara kommer att ha en representant i Forum förstärker detta behovet av ett effektivt samarbete.

En ny uppgift och en stor utmaning för tillsyn kommer att vara att avgöra om ämnen ska registreras eller om de faller utanför tillämpningsområdet i REACH eller om de täcks av något av de många undantagen. Detta kräver kunskap om andra EU lagstiftningar som nämns i REACH liksom en generell kunskap i kemi och processteknologi.

De mest farliga ämnena kommer i framtiden att listas i ett annex till förordningen och kommer att behöva auktoriseras för viss användning. Auktorisation kommer också att bli en ny viktig uppgift för tillsyn, t.ex. kommer det att bli en utmaning att kontrollera alla undantag och hur villkor följs av nedströmsanvändare i leverantörskedjan (när nedströmsanvändare kan använda sin leverantörs auktorisation).

Delar av REACH förslaget består av existerande lagstiftning, t.ex. begränsningdirektivet (Direktiv 76/769/EEG) och säkerhetsdatabladsdirektivet (Direktiv 91/155/EG). Tillsyn av redan existerande regler kommer att fortsätta efter att REACH har trätt ikraft, t.ex. om ämnen/beredningar är klassificerade korrekt, information i säkerhetsdatabladen och hur de stämmer överens med märkningen. Det finns dock ett behov av att utreda hur REACH förhåller sig till andra speciallagstiftningar inom EU, t.ex. om begränsningar i REACH också täcker varor som kan anses vara leksaker eller medicin-tekniska produkter.

Tillsyn enligt REACH kommer att behöva tillgång till relevant information i kemikaliemyndighetens databas, t.ex. registrerinsnummer, tidsbegränsningar, villkor, "sun-set" datum, undantag och notifieringar från nedströmsanvändare. REACH innehåller dock inte någon tydlig skrivning om att tillsynsmyndigheter har tillgång till databasen och till konfidentiell information.

Det globala harmoniserade systemet (GHS) kommer troligtvis att som en förordning träda i kraft samtidigt som REACH. Detta betyder att det är nödvändigt att utreda hur dessa förordningar kommer att fungera tillsammans eftersom både GHS och REACH reglerar klassificering och information i säkerhetsdatablad.

Nedströmsanvändarperspektivet har inte granskats annat än översiktligt i detta projekt, men eftersom de är en betydande grupp i de nordiska länderna, skulle det vara av intresse att gå vidare och granska hur tillsy- 
nen bör utformas över sådana företag. Det är också viktigt att notera att ett och samma företag kan vara importör, tillverkare och nedströmsanvändare samtidigt. I sådana fall kan REACH beröra företaget och därmed tillsynen på flera olika sätt.

Återkoppling från tillsynsaktiviteter till den behöriga myndigheten och/eller till kemikaliemyndigheten skulle kunna vara av värde, t.ex. hur ämnen/beredningar används, om villkor följs eller om de är omöjliga att följa, ämnen som skulle kunna vara kandidater för auktorisation eller begränsningar och resultat av övervakning/mätningar. Om detta anses viktigt behöver det utredas vidare hur denna återkoppling ska ske.

Första läsningen av kommissionens REACH förslag har nu avslutats av rådet och parlamentet. Den andra läsningen förväntas att avslutas under hösten 2006 vilket då medför att REACH förmodligen kommer att träda i kraft under våren 2007. 



\section{Glossary and abbreviations}

$\begin{array}{ll}\text { CA } & \text { Competent Authority } \\ \text { CAS } & \text { Chemical Abstract Service } \\ \text { C\&L } & \text { Classification and labelling } \\ \text { CLEEN } & \text { Chemical Legislation European Enforcement Network } \\ \text { CMR } & \text { Carcinogenic, Mutagenic or toxic for Reproduction } \\ \text { CSA } & \text { Chemical Safety Assessment } \\ \text { CSR } & \text { Chemical Safety Report } \\ \text { CWG } & \text { Commission Working Group } \\ \text { DU } & \text { Downstream User } \\ \text { ECLIPS } & \text { European Classification and Labelling Inspections of } \\ & \text { Preparations including Safety data sheets } \\ \text { EINECS } & \text { European Inventory of Existing Commercial Chemical } \\ & \text { Substances } \\ \text { ELINCS } & \text { European List of Notified Chemical Substances } \\ \text { EPA } & \text { Environmental Protection Agency } \\ \text { ES } & \text { Exposure Scenarios } \\ \text { EU } & \text { European Union } \\ \text { GHS } & \text { Global Harmonised System } \\ \text { I } & \text { Importer } \\ \text { M } & \text { Manufacturer } \\ \text { MS } & \text { Member States } \\ \text { NONS } & \text { Notification of New Substances } \\ \text { PBT } & \text { Persistent, Bio accumulative and Toxic substances } \\ \text { PIC } & \text { Prior Informed Consent } \\ \text { POPs } & \text { Persistent Organic Pollutants } \\ \text { PPORD } & \text { Product and process orientated research and development } \\ \text { REACH } & \text { Registration, Evaluation, Authorisation and Restriction of } \\ \text { RIP } & \text { Chemicals } \\ \text { RMM } & \text { Reach Implementation Projects } \\ \text { SDS } & \text { Risk Management Measures } \\ \text { SME } & \text { Safety Data Sheet } \\ \text { SR\&D } & \text { Small and Medium sized enterprises } \\ \text { SVHC } & \text { Scientific research and development } \\ \text { TGD } & \text { Substances of very high concern } \\ \text { vPvB } & \text { Technical Guidance document } \\ & \text { very Persistent, very Bio accumulative substances } \\ & \end{array}$



Appendices 


\section{Work Flow - REACH inspection}

\section{START}

Is there any manufacture/import of substances or import of substances

in preparations?

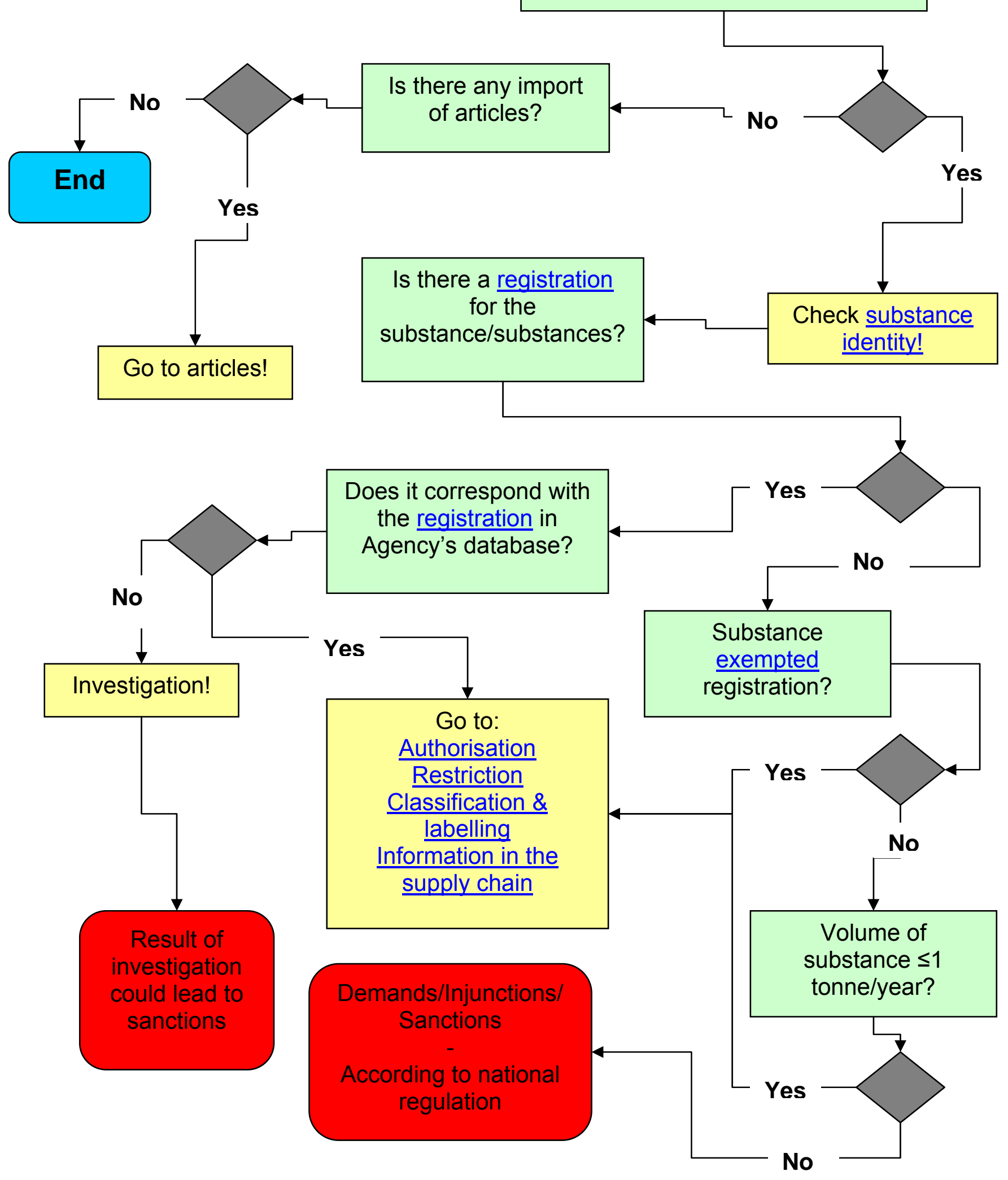


According to definitions in Article 3:

"Substance means a chemical element and its compounds in the natural state or obtained by any manufacturing process, including any additive necessary to preserve its stability and any impurity deriving from the process used, but excluding any solvent which may be separated without affecting the stability of the substance or changing its composition"

Annex la states in "1.1 Identification of the substance or preparation":

"The term used for identification shall be identical to that provided on the label as set out in Annex VI to Directive 67/548/EEC. For substances subject to registration, the term shall be consistent with that provided under registration."

Means of identifying substance (Annex IV, 2.1):

- Name in the IUPAC nomenclature or other international chemical name

- Other names (usual name, trade name, abbreviation)

- EINECS or ELINCS number

- CAS name and CAS number

- Other identity code 


\section{Checklist}

- Is the substance registered i.e. is there a registration number available, and does the tonnage manufactured or imported per year correspond to the tonnage level for the registration

- Is the substance used according to the identified use in the registration

- Is there a safety data sheet (SDS) available (when it is required) - and in cases where registration is above 10 tonnes/year - is the information in the SDS consistent with the information in the CSA/CSR, exposure scenarios prepared for identified uses and risk reduction measures followed and complied with

If the substance hasn't been registered then the inspector should check if:

- the substance is within the scope of the registration duty or not,

- there is an exemption from the registration duty according to Annexes II and III applicable for the substance

- the substance is only used in biocides and/or pesticides

- there is a PPORD notification relevant for the substance, if yes the inspector has to check if the substance has a notification number and if the conditions set in the PPORD decision from the Agency are met

- a phased-in registration is applicable

Note

- that Article 33 specifies an obligation for all actors in the supply chain to keep information at least 10 years after they last manufactured, imported, supplied or used the substance, on its own or in a preparation. However the Article stipulates that the information should only be available to any Competent Authority of the Member State.

- that it will be a specific challenge for inspectors to obtain information about substances in unclassified preparations as well as unclassified substances in classified products.

- that some companies probably consider themselves as downstream users formulating preparations instead of manufacturers of substances. A blend of substance $a, b$ and $c$, may result in a blend of substances $b$ and $f$. Consequently the result could be a substance for which the obligation to register should be considered. A good knowledge of chemistry is therefore needed both in companies and by enforcement authorities. 


\section{Exemptions from REACH-regulation and Title II Registration of substances:}

Back

\section{Checklist}

Check whether substance is covered by exemptions below:

In accordance with Article 2, substances mentioned below are exempted from the entire regulation:

- radioactive substances within the scope of Council Directive 96/29/Euratom

- substances, on their own, in a preparation or in an article, which are subject to customs supervision, provided that they do not undergo any treatment or processing, and which are in temporary storage, or in a free zone or free warehouse with a view to re-exportation, or in transit

- non-isolated intermediates.

Article 4 mentions substances exempted from registration:

- a substance used in medicinal products for human or veterinary use within the scope of Regulation (EEC) No 2309/93, Directive 2001/82/EC of the European Parliament and of the Council and Directive 2001/83/EC of the European Parliament and of the Council

- a substance used as a food additive in foodstuffs within the scope of Council Directive 89/107/EEC

- a substance used as a flavouring in foodstuffs within the scope of Commission Decision 1999/217/EC

- a substance used as an additive in feeding stuffs within the scope of Council Directive 70/524/EEC

- a substance used in animal nutrition within the scope of Council Directive 82/471/EEC

Exempted from title II, Registration, are also (Article 4):

- substances in Annex II

- substances covered by Annex III

- substances (on their own or in a preparation) registered and exported from Community by an actor in the supply chain and re-imported into Community by another actor in the same supply chain who can show:

o that the substance being re-imported is the same as the exported substance

0 he (the re-importer) has been provided with information in accordance with Article 30 (information for substances and preparations for which a SDS is not required, e.g. registration number, any restrictions...) and 31 (information up the supply chain of new information on hazardous properties or information that might question the appropriateness of RMM identified in a SDS. ) 
- On-site isolated intermediates or transported isolated intermediates (NB: they have to be registered in accordance with Chapter 4)

- Polymers are exempted from registration, but non-registered monomer substance(s) or other non-registered substance(s) should sometimes be registered - Article 5.3.

- PPORD (article 7):

If a substance is manufactured or imported for the purposes of PPORD there is no duty for registration for 5 years if:

- There is a number of listed customers

- Quantities are/should be limited and for the purpose of PPORD

- Notification to Agency of:

0 Identity of $\mathrm{M} / \mathrm{l}$

o Identity and classification (if any) of substance

o Estimated quantity

o List of customers

o Info on R\&D programme 
In accordance with Article 9 the following should be supplied to Agency:

- Technical dossier including:

o Identity of $\mathrm{M} / \mathrm{I}$ and substance

o Information on manufacture and all identified uses

o Classification \& labelling of substance

o Guidance on safe use of substance

o Summaries (or robust study summaries if required under Annex I - see 1.1.4 and 3.1 .5 in this Annex) of information derived from information on substance (Annexes $\mathrm{V}$ to IX)

o Statement as to whether or not information has been generated by testing on vertebrate animals

o Proposals for testing

o Declaration/Agreement that summaries/robust study summaries may be shared against payment

- Chemical Safety Report (CSR)

A Chemical Safety Assessment (CSA) and a Chemical Safety Report (see Annex I) are to be completed for

- All substances subject to registration, if:

o Quantities manufactured or imported of $\geq 10$ tonnes/year, and

o For preparations over specific concentration limits (se article 13.2)

A CSR need not include information about risks to human health from end uses of substances

- In food contact materials

- In cosmetic products

CSA should include: (art. 13.3-4)

- Human health hazard assessment, also physicochemical properties

- Environmental hazard assessment

- PBT and vPvB assessment

If this leads to a classification of substance as dangerous or substance is assessed to be a PBT or VPVB, CSA should also include (art. 13.4):

- Exposure assessment (should address all identified uses)

- Risk characterisation (should address all identified uses) 


\section{Authorisation:}

\section{Checklist}

- is the use exempted authorisation in accordance with Article 53, 3-7

- is there an authorisation granted for that particular use or whether the use is exempted in a granted authorisation

- any conditions or time limits related to the authorisation or the exemption

- whether the substance is labelled with an authorisation number

- whether a substance on its own, in a preparation or incorporated in an article is included on Annex XIII - and if it is - check whether the sunset date or any other timelimit is exceeded or not

- whether the downstream user uses the substance in accordance with the conditions of an authorisation granted to an actor up in the supply chain

- whether the downstream user has notified his use of the substance to the Agency, time for the first delivery

\section{Exemptions:}

o substances which are waste and treated in a waste treatment installation in accordance with the conditions of a permit (Article 53.3)

0 use in SR\&D or PPORD <1 tonne/year.

0 Use in (article 53.5)

o PPP

o Biocidal products

o Medicinal products for human or veterinary use

o Food additives

0 Additives in animal feeding stuffs

o Flavourings in foodstuffs

o On-site isolated intermediate or transported isolated intermediate

o Motor fuels

o Fuel in mobile or fixed combustion plants of mineral oil products and use as fuels in closed systems

o Use in cosmetic products (only health, not hazardous for environment)

0 Use in food contact materials (only health, not hazardous for environment)

o Uses in preparations where PBT, vPvB and (54.f) are below $<0,1 \%$

o Uses in preparations below concentration limits which result in the classification of the preparation as dangerous

What Annex XIII will specify:

o Identity and intrinsic property of substance

o Sunset date - date from which placing on the market/use is to be prohibited, unless an authorisation is granted

o Date/dates before which applications must be received if applicant wishes to continue to use/place substance on the market after sunset date

o Review periods, uses/categories of uses exempted and conditions (monitoring) if any 
Restrictions:

\section{Checklist}

- Is the substance listed on Annex XVI or XVII

- Is there any specific conditions given in the actual restriction with specific focus on the user area

- is there sufficient information about the composition of preparation or article to judge if substances could be restricted or not

- is there a verification of any scientific research or development (exempted)

- is there any clarification of other regulations that could cover the actual item 


\section{Classification and labelling:}

\section{Checklist}

- Check classification of substances and preparations, compare with inventory list and EU-harmonised classification.

- Check that a notification to the Agency has been made in accordance with Article 110 , if not submitted as a part of a registration dossier.

- Enforcement activities directed towards the inventory list could be an important contribution to remove divergences, if any. This requires either a lot of competence or access to competence/expertise.

Note that GHS will enter into force in the near future and that this new regulation will affect the classification and labelling. 


\section{Checklist}

- Is the information, e.g. SDS or other information, communicated in accordance with the regulation?

- Is the information in the SDS relevant?

- Is the information in the SDS in accordance with the information on the label? 